\title{
C5.0 Karar Ağacı Algoritması ile Öğretmenlerin FeTeMM Farkındalıklarının İncelenmesi
}

\author{
Neșe DOKUMACI SÜTÇÜ1
}

\begin{abstract}
Öz: Araştırmada, öğretmenlerin FeTeMM farkındalıklarını yordayan değişkenleri ve değişkenlerin önem sırasını belirlemek amaçlanmıştır. Araştırmanın katılımcıları, 2020-2021 eğitim-öğretim yılı bahar döneminde Diyarbakır'da görev yapan 267 öğretmenden oluşmaktadır. İlişkisel tarama modelinin kullanıldığı araştırmada veriler, "Kişisel Bilgi Formu" ve "FeTeMM Farkındalık Ölçeği" ile toplanmıştır. Verilerin analizinde İki Aşamalı Kümeleme Analizi ve C5.0 Karar Ağacı Algoritması kullanılmıştır. Araştırmada FeTeMM Farkındalık Ölçeği'nin her üç boyutuna ilişkin öğretmenlerin çoğunun orta düzey farkındalığa sahip oldukları ortaya çıkmıştır. Bununla birlikte ortaya çıkan bir başka bulgu ise "öğrenciye etkisi" boyutu üzerinde etki düzeyi en yüksek olan yordayıcı değişkenin öğretmenlerin görev yaptıkları okulların sosyoekonomik düzeyleri, "derse etkisi" ve "öğretmene etkisi" boyutları üzerinde etki düzeyi en yüksek olan yordayıcı değişkenin ise öğretmenlerin öğrenim durumları olduğudur.
\end{abstract}

Anahtar Sözcükler: FeTeMM, Farkındalık, İki aşamalı kümeleme analizi, Karar ağacı, C5.0 algoritması

\section{Examination of the STEM Awareness of teachers with C5.0 Decision Tree Algorithm}

\begin{abstract}
In the study, it was aimed to determine the variables that predicted the STEM awareness of the teachers and the order of importance of the variables. The participants of the study consisted of 267 teachers, who were working at Diyarbakir in the spring term of the 2020-2021 school year. In the study in which the relational (correlational) research model was used, the data were collected using the "Personal Information Form" and the "STEM Awareness Scale". Two-Stage Clustering Analysis and C5.0 Decision Tree Algorithm were used to analyze the data. In the study, it was revealed that mostly teachers had intermediate level awareness about all three dimensions of STEM awareness scale. However, another result is that the predictor variable with the highest level of influence on the dimension of "effect on the student" is the socioeconomic level of the schools where teachers work, the predictor variable with the highest level of influence on the dimensions of "effect on the lesson" and "effect on the teacher" is the teachers' educational status.
\end{abstract}

Keywords: STEM, Awareness, Two-stage clustering analysis, Decision tree, C5.0 algorithm 
Günümüzde düşünen, araştıran, sorgulayan, üreten, eleştirel düşünen ve yaratıcı bireylere olan ihtiyacın her geçen gün artmasıyla birlikte fen, teknoloji, mühendislik ve matematik alanlarının öğretme-öğrenme süreçleri için yeni ve farklı programların uygulanması gerekmektedir. Bu uygulamaların en güncel olanı FeTeMM (STEM) eğitim ve uygulamalarıdır (Yıldırım ve Altun, 2015). FeTeMM, Fen, Teknoloji, Mühendislik ve Matematik kelimelerinin baş harflerinden oluşmuş bir kısaltmadır ve STEM (Science, Technology, Engineering, Mathematics) kelimesinin Türkçe karşılığıdır.

FeTeMM eğitimi fen bilimleri, teknoloji, mühendislik ve matematik bilgisinin disiplinler arası yöntem ile öğretilmesidir (Çolakoğlu ve Günay-Gökben, 2017). FeTeMM eğitimi, bu disiplinlerde öğrenme ve öğretmeyi ifade etmektedir (Gonzalez ve Kuenzi, 2012). FeTeMM eğitimi barındırdığı disiplinlerin günlük hayatta karşılaşılabilecek bir problem ile içerik arasında ilişki kurularak kaynaştırılmaya çalışılmasıdır (Duygu, 2018). Bvbee (2010), çoğu kişinin FeTeMM terimini geçmişte kastedilen şekliyle genellikle fen ve matematik anlamına gelecek şekilde yorumladığını, nadiren teknoloji ve mühendisliğe vurgu yapıldığını belirtmiştir. Bvbee (2010), bu durumun düzeltilmesi gereken bir konu olduğunu ve FeTeMM'in genellikle fen ve matematik ile ilgili bir terim olduğu gözlemine dayanarak teknoloji ve mühendisliğin daha fazla vurgulanması gerektiğini ifade etmiş ve FeTeMM'i fen ve matematiğe dayalı teknoloji ve mühendisliği öğreten bütünleşmiş bir yaklaşım olarak tanımlamıştır.

FeTeMM öğrencilerin fen bilimleri, teknoloji, mühendislik ve matematik disiplinlerinde iletişim kurma, yaşam boyu öğrenme, problem çözme, girişimcilik, sorumluluk, eleştirel ve yaratıcı düşünme gibi 21. yüzyıl becerilerinin geliştirilmesinde (Koyunlu-Ünlü ve Dere, 2019), sahip oldukları teorik bilginin uygulamaya, ürüne ve yenilikçi buluşlara dönüştürülmesinde önemli katkılar sağlamaktadır (Güleryüz, Dilber ve Erdoğan, 2019). Bu eğitimin temel amacı, bilgiyi ezberlemek veya depolamak yerine öğrencilere süreçte aktif oldukları, üretim yaptıkları ve öğrendiklerini somutlaştırarak kullanılabilir hale getirdikleri bir yaklaşım sunmaktadır (Pehlivan ve Uluyol, 2019). Thomasian'a (2011) göre FeTeMM eğitiminin iki temel amacı vardır. İlki, fen, teknoloji, mühendislik ve matematik alanlarında eğitime başlamak ve kariyer yapmak için hazırlanan öğrenci sayısını artırmaktır. İkinci hedef ise tüm öğrencilerin temel FeTeMM bilgisindeki yeterliliğini artırmaktır. Bu hedef, öğrencilerin ve çalışanların sorunları değerlendirme, FeTeMM kavramlarını kullanma ve günlük yaşamlarında yaratıcı çözümler uygulama becerilerini geliştirmek için tasarlanmıştır.

FeTeMM eğitimi, son yıllarda Amerika Birleşik Devletleri, Japonya, Çin ve birçok Avrupa Birliği ülkesinde hem resmi (örneğin, sınıflar) hem de resmi olmayan ortamlarda (örneğin, okul sonrası programlar) okul öncesinden doktora sonrasına kadar tüm sınıf seviyelerinde eğitim faaliyetlerini içermektedir (Gonzalez ve Kuenzi, 2012). Tüm dünyada olduğu gibi Türkiye'de de FeTeMM disiplinlerinin bütünleştirilmesi ile ilgili çabalar, uygulamaların sayısı artmıştır (Ergün ve Balçın, 2019). Adkins'e (2012) göre, bu artışın temelinde gelecekte olması beklenen büyük teknolojik yeniliklerin, FeTeMM alanlarında yapılacak çalışmalara bağlı olması yer almaktadır (Korkut-Owen ve Erarslan-Çapan, 2017; Korkut-Owen ve Mutlu, 2016). Bu anlamda Milli Eğitim Bakanlığı (MEB, 2016) tarafından FeTeMM Eğitim Raporu yayınlanmıştır. Rapora göre, FeTeMM eğitimine yönelik model önerisinde bulunulmuş, FeTeMM eğitimi merkezlerinin kurulması, FeTeMM eğitimi ile ilgili araştırmaların yapılması, FeTeMM'e yönelik öğretmenlere eğitim verilmesi, FeTeMM'e göre öğretim programlarının güncellenmesi ve okullarda FeTeMM eğitiminin verilebilmesi için gerekli materyallerinin tedarik edilmesi gibi konulara değinilmiş ve öneri niteliğinde bir FeTeMM Eğitimi Eylem Planı sunulmuştur. Bununla birlikte bir başka uygulama Milli Eğitim Bakanlığının da dâhil olduğu Avrupa'da FeTeMM eğitimini Scientix Portalı aracılığıyla yaygınlaştırmayı amaçlayan akademisyenlere, öğretmenlere, okul yöneticilerine, ailelere ve FeTeMM eğitimi ile ilgilenen tüm kişilere açık olan Scientix Projesidir. Scientix Portalı, 2010 yılı Mayıs ayında kullanıma açılmış olup, portalda öğretmenlerin derslerinde yararlanabilecekleri, öğrencilerin birçok becerisini geliştirmeye yönelik sorgulama temelli FeTeMM eğitimi projeleri ve materyalleri paylaşılmaktadır. Bu proje ile Türkiye çapında FeTeMM eğitimi farkındalığını arttırmak amacıyla çalıştaylar düzenlenmektedir (Scientix Projesi, 2020).

Alanyazın incelendiğinde, FeTeMM eğitiminin öğrencilere birçok önemli katkı sağladığı dikkat çekmektedir. Örneğin, Gülseven (2020) tarafından yapılmış olan bir araştırmada, argümantasyon temelli FeTeMM eğitiminin öğrencilerin akademik başarı ve argümantasyon seviyelerine etkisinin olumlu olduğu 
sonucuna ulaşılmıştır. Balcı (2020) tarafından yapılmış olan başka bir araştırmada, FeTeMM etkinlikleri ortaokul öğrencilerinim matematiğe yönelik tutumlarında olumlu bir artışa sebep olmuştur. Bahçe'nin (2019) yapmış olduğu araştırmada, FeTeMM uygulamaları ile destekli derslerin işlenmesi sayesinde öğrencilerin etkinliklerde akıl yürütme, mühendislik, ilişkilendirme ve iletişim becerilerinin ortaya çıtığı ve bu becerilerin uygulamayı olumlu etkilediği sonucuna ulaşılmıştır. Ergün ve Balçın (2019) yapmış oldukları araştırmada, FeTeMM eğitiminde kullanılan probleme dayalı öğrenmenin öğrenci başarısını arttırdığını tespit etmişlerdir. Akgündüz ve Akpınar (2018) yapmış oldukları araştırma ile okul öncesi eğitiminde STEM uygulamaları ile öğrencilerin yaratıcllık, eleştirel düşünme, işbirliği yapma ve iletişim kurma gibi 21. yüzyıl becerilerinin geliştiği tespit edilmiştir. Duygu (2018) tarafından fen bilgisi öğretmen adayları ile yapılmış olan bir araştırmada, simülasyon tabanlı sorgulayıcı öğrenme ortamında gerçekleştirilen FeTeMM eğitiminin öğretmen adaylarının bilimsel süreç becerilerinin gelişiminde olumlu etkiye sahip olduğu ortaya çımıştır. Yıldırım (2016) tarafından FeTeMM eğitimi ile ilgili yapılmış olan 34 çalışmanın incelendiği bir meta-sentez araştırmasında ise FeTeMM eğitiminin akademik başarı, problem çözme, yaratıcı düşünme, bilimsel süreç becerileri, tutum, ilgi ve motivasyonu geliştirdiği ortaya çıkmıştır.

Araştırma sonuçlarından yola çıkılarak, problem çözme, derinlemesine düşünme, projeleri yönetme, çeşitli teknoloji ve bilgi araçlarını kullanma gibi becerilere sahip olmaları için öğrencilerin öğrenme deneyimleri sağlayabilen FeTeMM eğitimini almalarına ihtiyaç oldukları söylenebilir (Milaturrahmah, Mardiyana ve Pramudya, 2017). Ülkemizde özellikle son yıllarda farklı eğitim kademelerinde, okulda ya da okul dışı ortamlarda çeşitli FeTeMM etkinlikleri yürütülmektedir (Pehlivan ve Uluyol, 2019). Bu eğitimin gerçek amacına ulaşabilmesi için geleceğin disiplinler arası problemlerine çözüm üretecek bireyleri yetiştirecek öğretmenlerin bu konuda ilgili, bilinçli ve donanımlı olmaları gerekmektedir. Dolayısıyla süreci yönlendirecek olan öğretmenlerin FeTeMM eğitimi sürecini etkili bir şekilde planlayabilmeli, gerekli materyalleri ve eğitim ortamını hazırlayabilmelidir (Çevik, Danıştay ve Yağcl, 2017). Her türlü eğitim reformun temel taşı öğretmenler olduğuna göre (Desimone 2009; Fore, Feldhaus, Sorge, Agarwal ve Varahramyan, 2015; Guskey 2002), öğretmenlerin rolü öğrencilere fen, teknoloji, mühendislik ve matematiğin bütünleştirilmesi için rehberlik yaparak öğrencileri üst düzey düşünme, buluş ve inovasyon yapabilme, ürün geliştirme seviyesine ulaştırmaktır (MEB, 2018). FeTeMM eğitiminin amacına uygun bir şekilde gerçekleştirilebilmesi, öğretmenlerin bu konudaki farkındalık, mesleki bilgi, deneyim ve becerileri ile doğrudan ilişkilidir. Buna rağmen Püsküllü (2019), Daşdemir, Cengiz ve Aksoy (2018) tarafından FeTeMM eğitimi ile ilgili yapılmış çalışmaların incelendiği doküman inceleme araştırmalarında, örneklem grubunun öğretmenler olduğu araştırmaların sınırlı sayıda olduğu ortaya çıkmıştır. FeTeMM eğitimi farkındalığı FeTeMM eğitimi konusunda bilinçli ve duyarlı olmak olduğuna göre (Koyunlu-Ünlü ve Dere, 2019) öğretmenlerin FeTeMM eğitimine ilişkin farkındalıklarının belirlenmesi önem taşımaktadır. Alanyazın taramasında öğretmenlerin FeTeMM (STEM) eğitimi farkındalığı ile yapılmış olan araştırmalarda genellikle öğretmenlerin FeTeMM farkındalık düzeylerinin çeşitli değişkenlere göre incelendiği ortaya çıkmıştır. Örneğin; Ciğerci'nin (2020) yapmış olduğu araştırmada, öğretmenlerin FeTeMM eğitimine yönelik farkındalıkları incelenmiş ve öğretmenlerin farkındalıklarının yüksek düzeyde olduğu tespit edilmiştir. Ayrıca araştırmada öğretmenlerin FeTeMM eğitimine yönelik farkındalıklarının cinsiyet, yaş, kıdem, çalıştıkları pozisyon, mezun olunan program değişkenlerine göre anlamlı düzeyde farklılaşmadığı tespit edilirken, FeTeMM eğitimi alanlar ile almayanlar arasında istatiksel olarak anlamlı düzeyde bir farklılık bulunmuştur. Özdemir ve Cappellaro (2020) tarafından yapılmış olan bir araştırmada, sınıf öğretmenlerinin FeTeMM farkındalık düzeylerini belirlemek ve uygulamalara yönelik görüşlerini tespit etmek amaçlanmıştır. Araştırma bulgularına göre; sınıf öğretmenlerinin FeTeMM eğitimi farkındalıklarının cinsiyet, mesleki kıdem ve mezun olunan fakülte türüne göre farklılaşmadığı ortaya çıkmıştır. Nitel bulgulara göre ise sınıf öğretmenlerinin FeTeMM eğitimi uygulamaları hakkında olumlu görüşe sahip oldukları sonucuna ulaşılmıştır. Baran, Baran-Türkan, Aslan-Efe ve Maskan'ın (2018) yapmış oldukları araştırmada, fen alanları öğretmenlerinin FeTeMM farkındalık düzeyleri çeşitli değişkenlere göre incelenmiştir. Araştırmada öğretmenlerin farkındalık düzeylerinin orta düzeyde olduğu; FeTeMM etkinlikleri yapan, öğrencilerin dersleri sevmeleri ve öğrenci başarısı konusunda sorumluluk hisseden öğretmenlerin farkındalık düzeylerinin yüksek olduğu tespit edilmiştir. Karakaya, Ünal, Çimen ve Yılmaz'ın (2018) yapmış oldukları araştırmada, fen 
bilimleri öğretmenlerinin STEM bilincinin farklı değişkenler açısından belirlenmesi amaçlanmış ve öğretmenlerin STEM yaklaşımına yönelik farkındalıklarında cinsiyet, mesleki deneyim, hizmet içi/kurs/seminer alma, eğitim düzeyine göre anlamlı farklılık olduğu belirlenmiştir. Bununla birlikte öğretmenlerin STEM yaklaşımına yönelik farkındalıklarında, sınıftaki öğrenci sayısı ve görev yapılan okul türüne göre anlamlı farklılık olmadı̆̆ı saptanmıştır. Çevik ve diğerleri (2017) tarafından yapılmış olan bir araştırmada, ortaokullarda görevli fen bilimleri, matematik ve bilişim teknolojileri öğretmenlerinin FeTeMM eğitimi farkındalıkları farklı değişkenlere göre değerlendirilmiş; öğretmenlerin cinsiyet ve branş değişkenleri arasında herhangi bir anlamlı bir farklılık bulunmazken, mezun olunan fakülte türü, eğitim durumları ve mesleki kıdem değişkenleri arasında anlamlı farklılıklar bulunmuştur. Yapılan alanyazın taramasında öğretmenlerin FeTeMM farkındalıklarını yordayan bağımsız değişkenlerin ve değişkenlerin önem sırasının incelendiği herhangi bir araştırmaya rastlanmamıştır. Bilimsel araştırmaların temel odağında bağımlı (yordanan) değişkenin üzerinde etkili olan bağımsız (yordayıcı) değişkenlerin belirlenmesi vardır. Çünkü bu yöntemle eğitim politikalarına yön veren uygulamalardan elde edilen karmaşık veriler üzerinden bağımlı değişkeni yordayan bağımsız değişkenlere dair maksimum bilgi elde edilebilir (Aksu ve ReyhanlığluKeçeoğlu, 2019). Bu nedenle bu araştırma ile öğretmenlerin FeTeMM eğitimi farkındalıkları üzerinde anlamlı etkisi olan yordayıcı değişkenlerin belirlenmesi ve önem sırasının ortaya konulması amaçlanmıştır.

\section{Yöntem}

\section{Araştırma Modeli}

Öğretmenlerin FeTeMM eğitimi farkındalıklarını incelemeyi amaçlayan bu araştırmada, ilişkisel (korelasyonel) tarama modeli kullanılmıştır. Bu model, iki veya daha fazla değişken arasındaki ilişkileri belirlemek ve bunların neden-sonuç üzerindeki etkilerini keşfetmek için kullanılmaktadır. Bu tür araştırmalar, daha akıllı tahminler yapılmasına yardımcı olmaktadır (Fraenkel, Wallen ve Hyun, 2012).

\section{Katılımcilar}

Araştırmanın katılımcıları, 2020-2021 eğitim-öğretim yılı bahar döneminde Diyarbakır'da görev yapan 267 öğretmenden oluşmaktadır. Araştırmanın katılımcıları hakkındaki genel bilgilere Tablo 1'de yer verilmiştir.

Tablo 1. Araştırmanın Katılımcıları Hakkındaki Genel Bilgiler

\begin{tabular}{|c|c|c|c|}
\hline \multicolumn{2}{|c|}{ Değişken } & \multirow{2}{*}{$\begin{array}{c}\text { Frekans } \\
153\end{array}$} & \multirow{2}{*}{$\begin{array}{c}\text { Yüzde } \\
57.3\end{array}$} \\
\hline Cincivet & Kadın & & \\
\hline Cinsiyet & Erkek & 114 & 42.7 \\
\hline \multirow{2}{*}{ Branş } & FeTeMM Branşları & 178 & 66.7 \\
\hline & FeTeMM Dışı Branşlar & 89 & 33.3 \\
\hline \multirow{5}{*}{ Kidem } & $1-5$ y1l & 69 & 25.8 \\
\hline & $6-10$ yil & 57 & 21.3 \\
\hline & $11-15$ y1l & 55 & 20.6 \\
\hline & $16-20 \mathrm{y} 1 \mathrm{l}$ & 51 & 19.1 \\
\hline & 21 yıl ve üzeri & 35 & 13.1 \\
\hline \multirow{4}{*}{ Öğrenim Durumu } & Lisans & 218 & 81.6 \\
\hline & Tezsiz Yüksek lisans & 16 & 6.0 \\
\hline & Tezli Yüksek lisans & 29 & 10.9 \\
\hline & Doktora & 4 & 1.5 \\
\hline \multirow{3}{*}{ Okul türü } & İlkokul & 55 & 20.6 \\
\hline & Ortaokul & 165 & 61.8 \\
\hline & Lise & 47 & 17.6 \\
\hline \multirow{4}{*}{ Okulların sosyoekonomik düzeyleri } & Düşük & 119 & 44.6 \\
\hline & Orta & 132 & 49.4 \\
\hline & Yüksek & 16 & 6.0 \\
\hline & Toplam & 267 & 100 \\
\hline
\end{tabular}


Tablo 1'de görüldüğü üzere, araştırmaya 153'ü (\%57.3) kadın, 114'ü (\%42.7) erkek olmak üzere toplam 267 öğretmen katılmıştır. Öğretmenlerden 178'i (\%66.7) FeTeMM branşları, 89'u (\%33.3) FeTeMM dışı branşlara sahiptir. Öğretmenlerden 69'u (\%25.8) 1-5 yıl; 57'si (\%21.3) 6-10 yıl; 55'i (\%20.6) 11-15 y1l; 51'i (\%19.1) 16-20 yıl; 35'i (\%13.1) 21 yıl ve üzeri kıdeme sahiptir. Öğretmenlerden 218'i (\%81.6) lisans; 16'sı (\%6.0) tezsiz yüksek lisans; $29^{\prime}$ u (\%10.9) tezli yüksek lisans ve 4'ü (\%1.5) doktora mezunudur. Öğretmenlerin 55'i (\%20.6) ilkokul; 165'i (\%61.8) ortaokul; 47'si (\%17.6) lisede görev yapmaktadır. Görev yaptıkları okulların sosyoekonomik açıdan düşük düzey olduğunu belirten 119 (\%44.6), orta düzey olduğunu belirten 132 (\%49.4) ve yüksek düzey olduğunu belirten 16 (\%6) öğretmen bulunmaktadır.

\section{Veri Toplama Aracı}

Araştırmaya katılan öğretmenlere "Kişisel Bilgi Formu" ve "FeTeMM Farkındalık Ölçeği" uygulanmıştır. Kişisel bilgi formunda; öğretmenlerin cinsiyetlerine, branşlarına, kıdemlerine, öğrenim durumlarına, görev yaptıkları okulların türlerine ve okulların sosyoekonomik düzeylerine ilişkin sorular yer almaktadır.

FeTeMM Farkındalık Ölçeği, Çevik (2017) tarafından geliştirilmiştir. Ölçek, ilk aşamada 24 maddeden oluşmaktadır. Ölçekteki maddeler beşli likert tipinde olup, kesinlikle katılıyorum (5), katılıyorum (4), kararsızım (3), katılmıyorum (2), kesinlikle katılmıyorum (1) şeklinde derecelendirilmiştir. Geçerlik ve güvenirlik çalışmaları kapsamında ilk olarak açımlayıcı faktör analizi gerçekleştirilmiş; "Öğrenciye Etkisi", "Derse Etkisi" ve "Öğretmene Etkisi" şeklinde üç boyuttan oluşan, 15 maddelik bir ölçek elde edilmiştir. "Öğrenciye Etkisi" boyutu 6 maddeden oluşmakta ve maddelerin yük değerleri .78 ile .63 arasında değişmekte; "Derse Etkisi" boyutu 5 maddeden oluşmakta ve maddelerin yük değerleri .77 ile .47 arasında değişmekte ve "Öğretmene Etkisi" boyutu 4 maddeden oluşmakta ve maddelerin yük değerleri .68 ile .48 arasında değişmektedir. Bu üç boyut toplam varyansın \%49,47'sini açıklamaktadır. İkinci olarak, doğrulayıcı faktör analizi uygulanmış ve ölçeğin üç boyutlu yapısı doğrulanmıştır $\left(X^{2} / \mathrm{sd}=1.80\right.$, RMSEA=.050, GFI=.92, $\mathrm{NFI}=.94, \mathrm{CFI}=.97, \mathrm{NNFI}=.96, \mathrm{SRMR}=.055)$. Ölçeğin, Cronbach's Alpha güvenirlik katsayısı hesaplanmış ve .82 olarak raporlanmıştır. Ölçeğe test tekrar test yöntemi uygulanmış, birinci uygulamada ölçeğin standart sapması ve ortalaması 0.52 ve 3.95; ikinci uygulamada 0.53 ve 3.91 olarak tespit edilmiştir. Pearson korelasyon katsayısı ise $\mathrm{r}=0.615$ olup, .001 düzeyinde anlamlı olduğu bulunmuştur. Böylelikle çalışma sonucunda öğretmenlerinin FeTeMM farkındalık düzeylerini belirlemek için kullanışlı, geçerli ve güvenilir bir ölçek elde edilmiştir.

Ölçeğin güvenirliği, bu araştırma kapsamında Cronbach Alfa yöntemiyle yeniden hesaplanmış ve güvenirlik katsayıs1 .85 olarak bulunmuştur. Büyüköztürk (2011)'e göre elde edilen değer .70 ve üzeri olduğu için ölçme aracının güvenilir olduğu söylenebilir.

\section{Verilerin Toplanması ve Analizi}

Araştırmaya ilişkin Dicle Üniversitesi Sosyal ve Beşeri Bilimler Etik Kurulu Başkanlığın'dan E-14679147663.05-13968 sayılı etik kurulu onayı alınmıştır. Daha sonra E-30769799-44-22269047 sayılı yazı ile İl Milli Eğitim Müdürlüğü'ne bağlı resmi ve özel okullarda görev yapan öğretmenlere veri toplama aracı uygulama talebi 10/03/2021 tarih 22108847 sayılı valilik onayı ile uygun görülmüştür. Gerekli izinler alındıktan sonra ölçek öğretmenlere Google Form aracılığıyla, gönüllük esasına dayalı bir şekilde uygulanmıştır.

Öğretmenlerin FeTeMM Farkındalık Ölçeği'ne vermiş oldukları cevaplardan elde edilen verilere; “SPSS Clementine 12.0" programı kullanılarak önce İki Aşamalı Kümeleme Analizi ve daha sonra C5.0 Karar Ağacı Algoritması uygulanmıştır.

İki Aşamalı Kümeleme Analizi, heterojen olan veri setini homojen alt kümelere bölmeyi ve elde edilen sürekli puanları kategorik puanlara dönüştürmeyi hedef almaktadır (Kayri, 2007). Böylelikle uygun, işe yarar ve özetleyici bilgiler elde etmede, araştırmacıya yardımcı olmaktır (Harrigan, 1985; Akt: Kayri, Elkonca, Şevgin ve Ceyhan, 2014). Büyük veri setlerinde uygulanabilmesi, kategorik ve sürekli değişkenleri işleyebilmesi, en uygun küme sayısını otomatik ya da isteğe bağlı olarak belirleyebilmesi ve elde edilen kümelerle uyum sağlamayan gözlemlerin istenildiğinde veri setinden çıarılabilmesi bu analizin en önemli özelliklerindendir (Ceylan, Gürsev ve Bulkan, 2017). 
Karar ağacı, veri setine bir dizi karar kuralları uygulayarak, veri setini daha küçük kümelere bölmek için kullanılmaktadır (Albayrak ve Koltan-Yılmaz, 2009). Karar ağaçları, örneklerin özellik değerlerini kullanarak, örnekleri sınıflandırır. Karar ağacındaki her düğüm, sınıflandırılacak örnekteki bir özelliği temsil etmektedir (Pandya ve Pandya, 2015). Karar ağaçlarında kullanılan C4.5, C5.0, ID3, CART, CHAID, QUEST gibi birçok algoritma mevcuttur. C5.0 algoritması, doğruluğu arttırmak için boosting algoritmasını kullanmaktadır. Dolayısıyla C5.0 algoritması, boosting ağaçları olarak da bilinmektedir (Çalış, Kayapınar ve Çetinyokuş, 2014). C5.0 algoritması kategorik hedef değişkenleri tahmin etmek amacıyla kullanılmaktadır. Hafızayı etkin kullanan algoritma daha küçük karar ağaçları oluşturmaya imkân tanımakta, verinin ayrıştırılması ve iyileştirilmesi için daha uygun çözümler sunmaktadır (Köse ve Ersöz, 2020; Pandya ve Pandya, 2015). Ayrıca bu modelden türetilen kurallar çok basit bir yoruma sahip olduğundan, modelin anlaşılması diğer model türlerine göre daha kolaydır (Pang ve Gong, 2009). Bu nedenle, bu araştırmada karar ağaçları algoritmalardan C5.0 tercih edilmiştir.

C5.0 karar ağacı algoritması kategorik hedef değişkenleri tahmin etmek amacıyla kullanıldığı için (Köse ve Ersöz, 2020) öğretmenlerin FeTeMM farkındalık puanları İki Aşamalı Kümeleme Analizi ile kategorik puanlara dönüştürülmüştür. Buna göre FeTeMM Farkındalık Ölçeği'nin "öğrenciye etkisi”, "derse etkisi" ve "öğretmene etkisi" boyutlarından elde edilen ortalama puanlar düşük, orta ve yüksek düzey olmak üzere homojen ve kategorik olarak üç kümeye ayrılmıştır. 1. Küme FeTeMM'e ilişkin düşük düzey, 2. Küme orta düzey (eşik değer), 3. Küme ise yüksek düzey farkındalığa sahip olan öğretmenlerden oluşmaktadır. Öğretmenlerin ölçeğin her bir boyutundan aldıkları ortalama puanlar homojen ve kategorik olarak üç küme üzerinden C5.0 algoritmasına dâhil edilmiştir. O halde kurulan modelde yordanan (bağımlı) değişken "öğrenciye etkisi", "derse etkisi" ve "öğretmene etkisi" boyutlarından elde edilmiş ortalama puanların kategorik hali (düşük-orta/eşik-yüksek); yordayıcı (bağımsız) değişkenler ise öğretmenlerin cinsiyetleri, branşları, kıdemleri, öğrenim durumları, görev yaptıkları okulların türleri ve okulların sosyoekonomik düzeyleridir.

\section{Bulgular}

FeTeMM Farkındalık Ölçeği'nin "öğrenciye etkisi” alt boyutuna ilişkin ortalama puanlara ait İki Aşamalı Kümeleme Analizi sonuçları Tablo 2' de verilmektedir.

Tablo 2. FeTeMM Farkındalık Ölçeği’nin “Öğrenciye Etkisi” Boyutuna ilişkin İki Aşamah Kümeleme Analizi Sonuçları

\begin{tabular}{|c|c|c|c|c|}
\hline Kümeleme & $\mathrm{N}$ & $\bar{X}$ & SS & $\%$ \\
\hline 1. Küme (Düşük düzey)-Öğrenciye etkisi-1 & 20 & 3.08 & 0.53 & 7.49 \\
\hline 2. Küme (Eşik/Orta düzey)- Öğrenciye etkisi-2 & 126 & 4.01 & 0.17 & 47.19 \\
\hline 3. Küme (Yüksek düzey)- Öğrenciye etkisi-3 & 121 & 4.87 & 0.18 & 45.32 \\
\hline
\end{tabular}

Tablo 2 incelendiğinde, 1 . kümede 20 (\%7.49) öğretmen yer almakta ve ortalamaları $3.08 \pm 0.53$ değerinde; 2. kümede 126 (\%47.19) öğretmen yer almakta ve ortalamaları $4.01 \pm 0.17$ değerinde ve 3 . kümede ise 121 (\%45.32) öğretmen yer almakta ve ortalamaları $4.87 \pm 0.18$ değerindedir. 2 . küme eşik değer olarak ele alınmıştır. Ortalamaları eşik değerin altında olan öğretmenlerin FeTeMM Farkındalık Ölçeği'nin “öğrenciye etkisi" boyutuna ilişkin düşük düzey, ortalamaları eşik değerin üstünde olan öğretmenlerin ise yüksek düzeyde farkındalığa sahip oldukları söylenebilir.

FeTeMM Farkındalık Ölçeği'nin "öğrenciye etkisi” boyutu üzerinde anlamlı etkisi olan yordayıcı değişkenlerin önem sırası Şekil 1'de verilmektedir. 


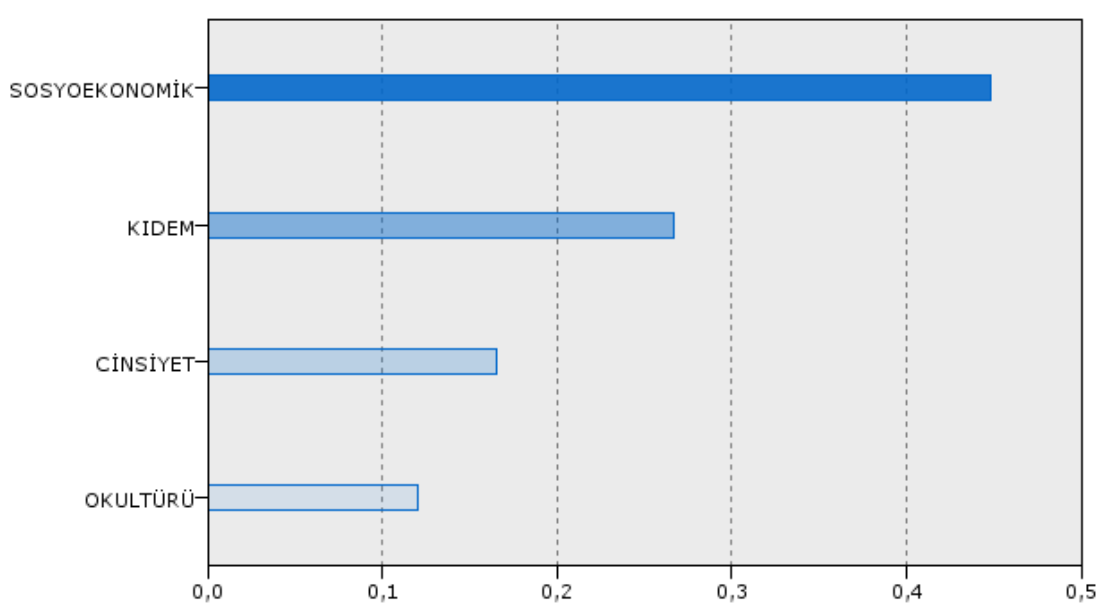

Şekil 1. FeTeMM Farkındalık Ölçeği'nin “Öğrenciye Etkisi” Boyutu Üzerinde Anlamlı Etkisi Olan Yordayıcı Değişkenlerin Önem Sırası

Şekil 1'de görüldüğü üzere "öğrenciye etkisi” boyutu üzerinde etki düzeyi en yüksek olan yordayıı değişken "okulların sosyoekonomik düzeyi"dir. Bu boyut üzerinde anlamlı etkisi olan diğer yordayıcı değişkenler sırasıyla "kıdem", "cinsiyet" ve "okul türü" dür.

FeTeMM Farkındalık Ölçeği'nin “öğrenciye etkisi” boyutuna ilişkin C5.0 algoritması ile elde edilen karar ağacı Şekil 2'de gösterilmektedir.

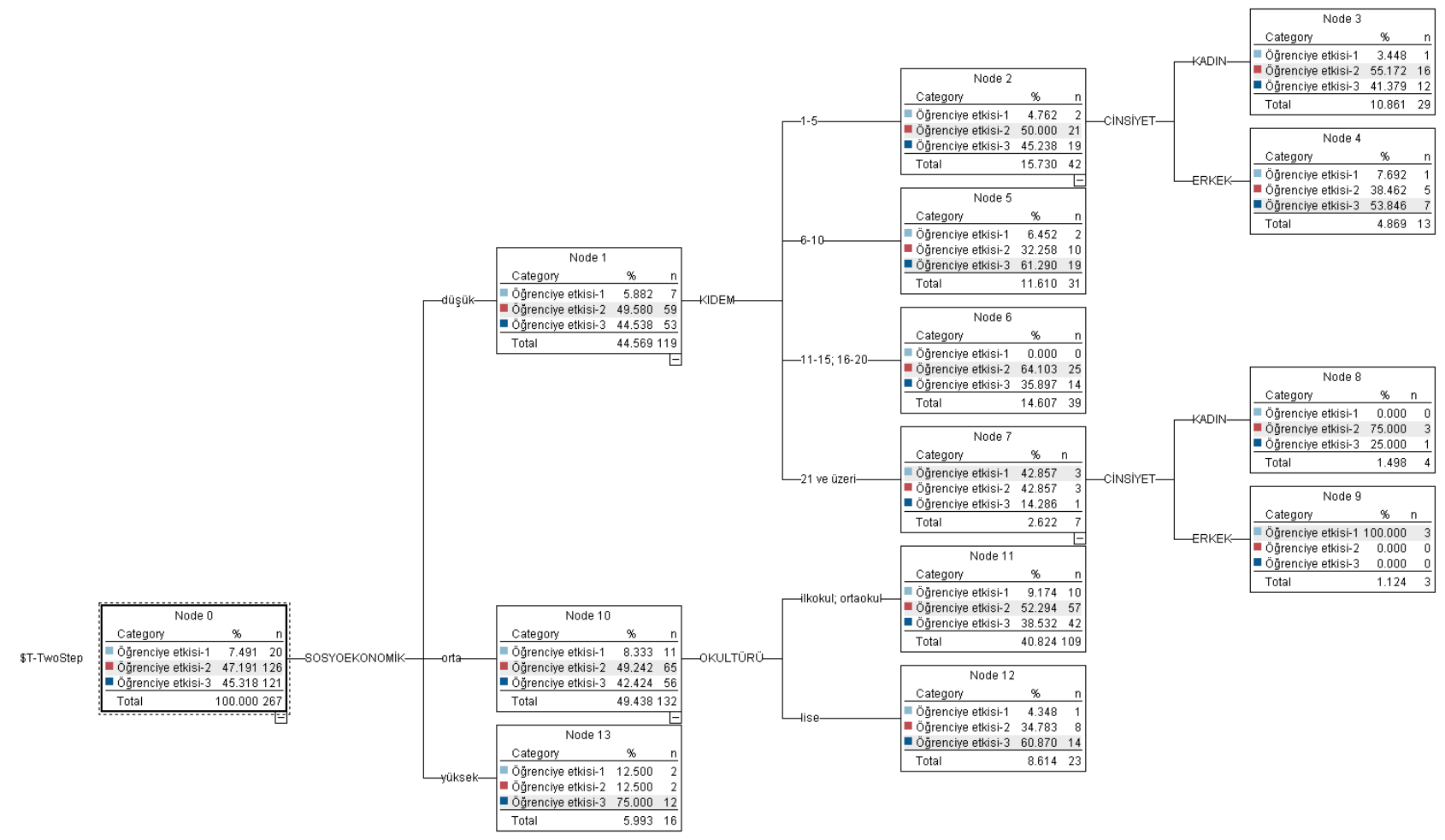

Şekil 2. FeTeMM Farkındalık Ölçeği' nin “Öğrenciye Etkisi” Boyutuna ilişkin C5.0 Algoritması ile Elde Edilen Karar Ağacı

Şekil 2 incelendiğinde, FeTeMM Farkındalık Ölçeği'nin “öğrenciye etkisi” boyutunu açılayan 13 düğüm olduğu görülmektedir. Bu boyutu en iyi açıklayan değişken "okulların sosyoekonomik düzeyleri"dir. Sosyoekonomik açıdan yüksek düzey okullarda görev yaptıklarını belirten öğretmenlerin \%75 gibi büyük çoğunluğu FeTeMM Farkındalık Ölçeği'nin “öğrenciye etkisi” boyutuna ilişkin yüksek düzeyde farkındalığa sahiptirler. Sosyoekonomik açıdan düşük düzey okullarda görev yaptıklarını belirten öğretmenlerin \%49.58 ve orta düzey okullarda görev yaptıklarını belirten öğretmenlerin \%49.24 gibi çoğunluğu FeTeMM 
Farkındalık Ölçeği' nin “öğrenciye etkisi” boyutuna ilişkin orta düzey farkındalığa sahiptirler.

Sosyoekonomik açıdan düşük düzey okullarda görev yaptıklarını belirten öğretmenlerin oluşturduğu kümeyi en iyi açılayan değişken “kıdem” dir. Bu değişken bağımlı değişkeni dört gruba ayırmıştır. Buna göre sosyoekonomik açıdan düşük düzey okullarda görev yaptıklarını belirten, 1-5 yıl kıdeme sahip olan öğretmenlerin \%50'si, 11-20 yıl kıdeme sahip olan öğretmenlerin \%64.10'u FeTeMM Farkındalık Ölçeği'nin “öğrenciye etkisi” boyutuna ilişkin orta düzey, 6-10 yıl kıdeme sahip olan öğretmenlerin \%61.29'u yüksek düzey farkındalığa sahiptirler. Sosyoekonomik açıdan düşük düzey okullarda görev yaptıklarını belirten, 21 yıl ve üzeri kıdeme sahip öğretmenlerin FeTeMM Farkındalık Ölçeği' nin “öğrenciye etkisi” boyutuna ilişkin düşük ve orta düzeyde farkındalığa sahip olanlarının yüzdesinin \%42.86 ile eşit olduğu tespit edilmiştir.

Sosyoekonomik açıdan düşük düzey okullarda görev yaptıklarını belirten, 1-5 yıl kıdeme sahip öğretmenlerin oluşturduğu kümeyi en iyi açılayan değişken "cinsiyet"tir. Buna göre sosyoekonomik açıdan düşük düzey okullarda görev yaptıklarını belirten, 1-5 yıl kıdeme sahip erkek öğretmenlerin \%53.85'i FeTeMM Farkındalık Ölçeği'nin "öğrenciye etkisi” boyutuna ilişkin yüksek düzey, kadın öğretmenlerin \%55.17'si orta düzey farkındalığa sahiptirler. Benzer şekilde sosyoekonomik açıdan düşük düzey okullarda görev yaptıklarını belirten, 21 yıl ve üzeri kıdeme sahip öğretmenlerin oluşturduğu kümeyi en iyi açıklayan değişken de "cinsiyet"tir. Buna göre sosyoekonomik açıdan düşük düzey okullarda görev yaptıklarını belirten, 21 yıl ve üzeri kıdeme sahip kadın öğretmenlerin \%75'i FeTeMM Farkındalık Ölçeği'nin “öğrenciye etkisi” boyutuna ilişkin orta düzey, erkek öğretmenlerin \%100'ü düşük düzey farkındalığa sahiptirler.

Sosyoekonomik açıdan orta düzey okullarda görev yaptıklarını belirten öğretmenlerin oluşturduğu kümeyi en iyi açıklayan değişken "okul türü"dür. Bu değişken bağımlı değişkeni iki gruba ayırmıştır. Buna göre sosyoekonomik açıdan orta düzey, ilk ve ortaokullarda görev yapan öğretmenlerin \%52.29'u FeTeMM Farkındalık Ölçeği'nin "öğrenciye etkisi" boyutuna ilişkin orta düzey, liselerde görev yapan öğretmenlerin $\% 60.87$ 'si gibi büyük çoğunluğu yüksek düzey farkındalığa sahiptirler.

FeTeMM Farkındalık Ölçeği'nin "derse etkisi” boyutuna ilişkin ortalama puanlara ait İki Aşamalı Kümeleme Analizi sonuçları Tablo 3'te verilmektedir.

Tablo 3. FeTeMM Farkındalık Ölçeği'nin “Derse Etkisi” Boyutuna ilişkin İki Aşamalı Kümeleme Analizi Sonuçları

\begin{tabular}{lcccc}
\hline Kümeleme & $\mathrm{N}$ & $\overline{\mathrm{X}}$ & $\mathrm{SS}$ & $\%$ \\
\hline 1. Küme (Düşük düzey)-Derse etkisi-1 & 83 & 3.23 & 0.19 & 31.09 \\
2. Küme (Eşik/Orta düzey)- Derse etkisi-2 & 144 & 3.87 & 0.22 & 53.93 \\
3. Küme (Yüksek düzey)- Derse etkisi-3 & 40 & 4.60 & 0.24 & 14.98 \\
\hline
\end{tabular}

Tablo 3'e göre, 1. kümede 83 (\%31.09) öğretmen yer almakta ve ortalamaları $3.23 \pm 0.19$ değerinde; 2 . kümede 144 (\%53.93) öğretmen yer almakta ve ortalamaları $3.87 \pm 0.22$ değerinde ve 3 . kümede ise 40 (\%14.98) öğretmen yer almakta ve ortalamaları $4.60 \pm 0.24$ değerindedir. 2. küme eşik değer olarak ele alınmıştır. Ortalamaları eşik değerin altında olan öğretmenlerin FeTeMM Farkındalık Ölçeği'nin "derse etkisi” boyutuna ilişkin düşük düzey, ortalamaları eşik değerin üstünde olan öğretmenlerin ise yüksek düzeyde farkındalığa sahip oldukları söylenebilir.

FeTeMM Farkındalık Ölçeği'nin "derse etkisi" boyutu üzerinde anlamlı etkisi olan yordayıcı değişkenlerin önem sırası Şekil 3'te verilmektedir. 


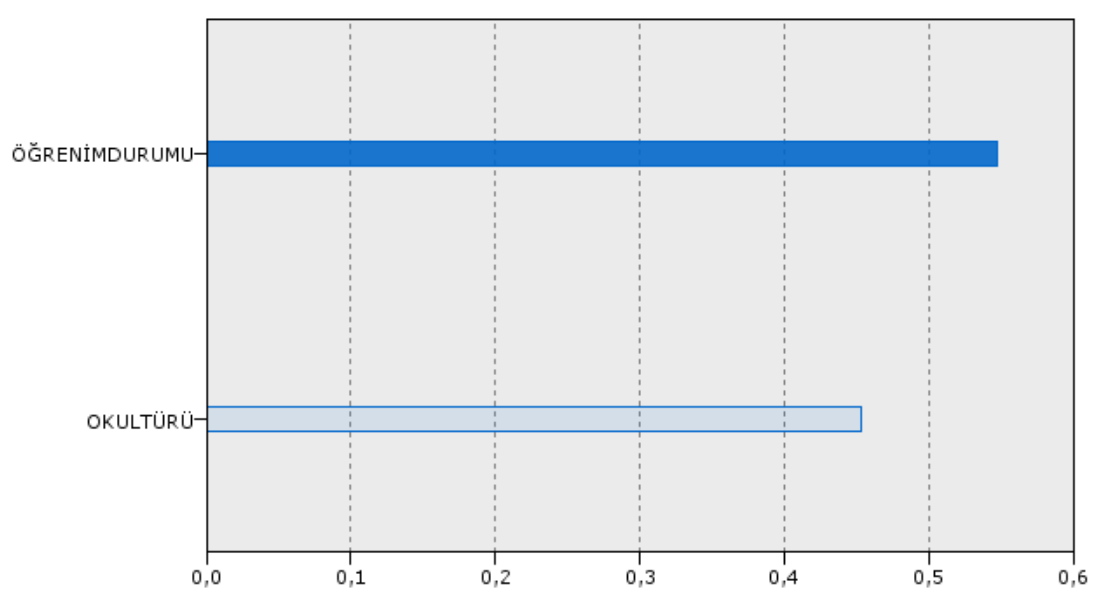

Şekil 3. FeTeMM Farkındalık Ölçeği'nin “Derse Etkisi” Boyutu Üzerinde Anlamlı Etkisi Olan Yordayıcı Değişkenlerin Önem Sırası

Şekil 3'te FeTeMM Farkındalık Ölçeği' nin “derse etkisi” boyutu üzerinde anlamlı etkisi olan iki yordayıcı değişken olduğu ve etki düzeyi en yüksek olan değişkenin "öğrenim durumu" olduğu görülmektedir. Bu boyut üzerinde anlamlı etkisi olan diğer yordayıcı değişken ise okul türü"dür.

FeTeMM Farkındalık Ölçeği'nin “derse etkisi” boyutuna ilişkin C5.0 algoritması ile elde edilen karar ağacı Şekil 4'te gösterilmektedir.

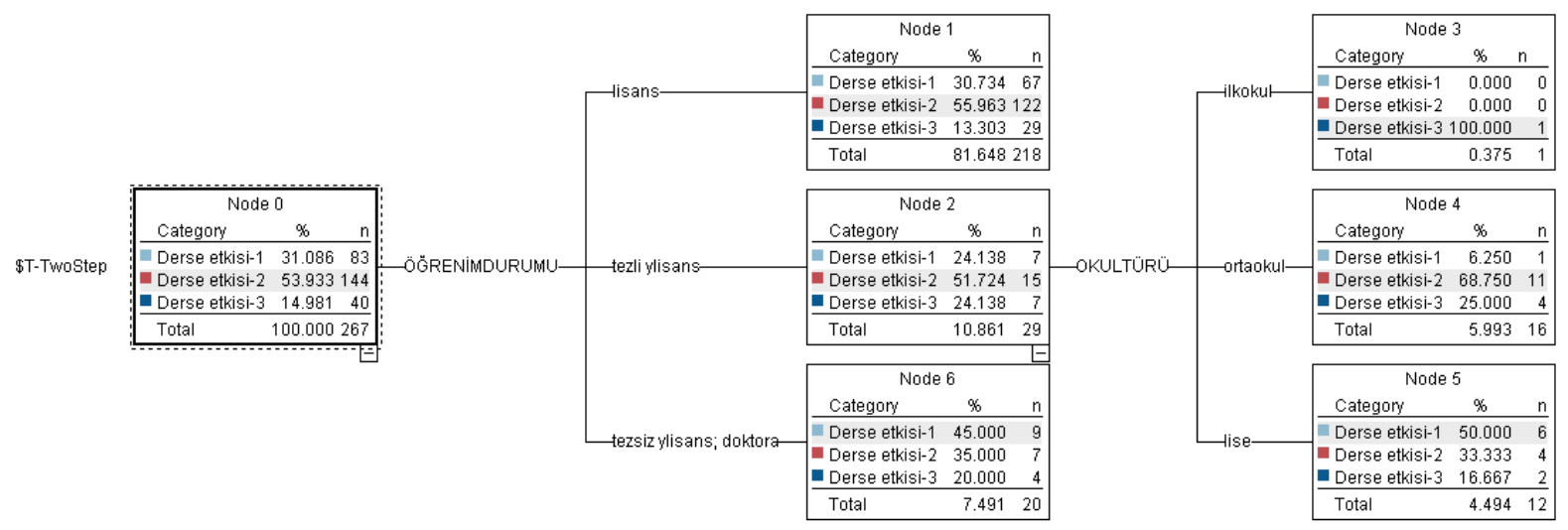

Şekil 4. FeTeMM Farkındalık Ölçeği' nin “Derse Etkisi” Boyutuna ilişkin C5.0 Algoritması ile Elde Edilen Karar Ağacı

Şekil 4 incelendiğinde, FeTeMM Farkındalık Ölçeği'nin "derse etkisi” boyutunu açıklayan 6 düğüm olduğu görülmektedir. Bu boyutu en iyi açıklayan değişken "öğrenim durumu"dur. Bu değişken bağımlı değişkeni üç gruba ayırmıştır. Buna göre lisans mezunu olan öğretmenlerin \%55.96'sl, tezli yüksek lisans mezunu olan öğretmenlerin \%51.72'si FeTeMM Farkındalık Ölçeği'nin "derse etkisi" boyutuna ilişkin orta düzey, tezsiz yüksek lisans ve doktora mezunu olan öğretmenlerin \%45'i düşük düzey farkındalığa sahiptirler.

Tezli yüksek lisans mezunu öğretmenlerin oluşturduğu kümeyi en iyi açıklayan değişken "okul türü"dür. Şekil 4'te tezli yüksek lisans mezunu olup, ilkokulda görev yapan bir öğretmenin olduğu ve FeTeMM Farkındalık Ölçeği'nin "derse etkisi" boyutuna ilişkin yüksek düzeyde farkındalığa sahip olduğu görülmektedir. Ayrıca tezli yüksek lisans mezunu olup, ortaokulda görev yapan öğretmenlerin \%68.75'i gibi büyük çoğunluğu FeTeMM Farkındalık Ölçeği'nin "derse etkisi” boyutuna ilişkin orta düzey; tezli yüksek lisans mezunu olup, lisede görev yapan öğretmenlerin \%50.00'si düşük düzey farkındalığa sahiptirler.

FeTeMM Farkındalık Ölçeği'nin “öğretmene etkisi” boyutuna ilişkin ortalama puanlara ait İki Aşamalı Kümeleme Analizi sonuçlarına Tablo 4'te yer verilmektedir. 
Tablo 4. FeTeMM Farkındalık Ölçeği'nin “Öğretmene Etkisi” Boyutuna ilişkin İki Aşamalı Kümeleme Analizi Sonuçları

\begin{tabular}{lcccc}
\hline Kümeleme & $\mathrm{N}$ & $\overline{\mathrm{X}}$ & $\mathrm{SS}$ & $\%$ \\
\hline 1. Küme (Düşük düzey)-Öğretmene etkisi 1 & 112 & 3.49 & 0.34 & 41.95 \\
2. Küme (Eşik/Orta düzey)- Öğretmene etkisi 2 & 122 & 4.15 & 0.20 & 45.69 \\
3. Küme (Yüksek düzey)-Öğretmene etkisi 3 & 33 & 4.91 & 0.12 & 12.36 \\
\hline
\end{tabular}

Tablo 4'e göre, 1. kümede 112 (\%41.95) öğretmen yer almakta ve ortalamaları $3.49 \pm 0.34$ değerinde; 2 . kümede 122 (\%45.69) öğretmen yer almakta ve ortalamaları $4.15 \pm 0.20$ değerinde ve 3. kümede ise 33 (\%12.36) öğretmen yer almakta ve ortalamaları $4.91 \pm 0.12$ değerindedir. 2 . küme eşik değer olarak ele alınmıştır. Ortalamaları eşik değerin altında olan öğretmenlerin FeTeMM Farkındalık Ölçeği'nin "öğretmene etkisi” boyutuna ilişkin düşük düzey, ortalamaları eşik değerin üstünde olan öğretmenlerin ise yüksek düzeyde farkındalığa sahip oldukları söylenebilir.

Şekil 5'te FeTeMM Farkındalık Ölçeği'nin "öğretmene etkisi” boyutu üzerinde anlamlı etkisi olan yordayııı değişkenlerin önem sırası verilmektedir.

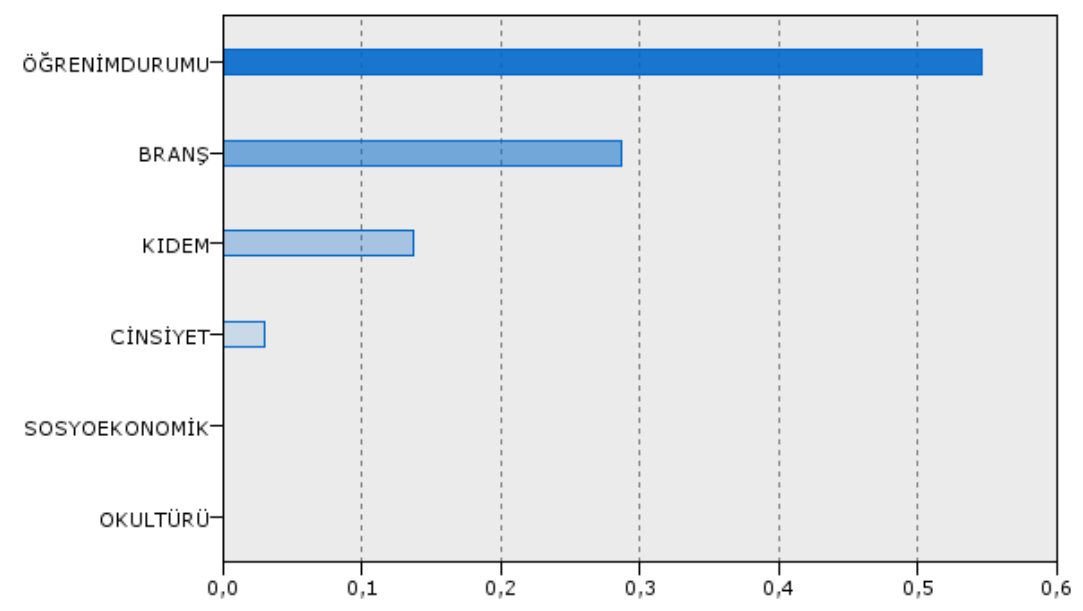

Şekil 5. FeTeMM Farkındalık Ölçeği'nin “Öğretmene Etkisi” Boyutu Üzerinde Anlamlı Etkisi Olan Yordayıcı Değişkenlerin Önem Sırası

Şekil 5 incelendiğinde "öğretmene etkisi" boyutu üzerinde etki düzeyi en yüksek olan yordayıcı değişkenin "öğrenim durumu" olduğu görülmektedir. Bu boyut üzerinde anlamlı etkisi olan diğer yordayıcı değişkenler ise sırasıyla "branş", "kıdem", "cinsiyet", "okulların sosyoekonomik düzeyi" ve "okul türü" dür.

FeTeMM Farkındalık Ölçeği'nin “öğretmene etkisi” boyutuna ilişkin C5.0 algoritması ile elde edilen karar ağacı Şekil 6'da gösterilmektedir. 


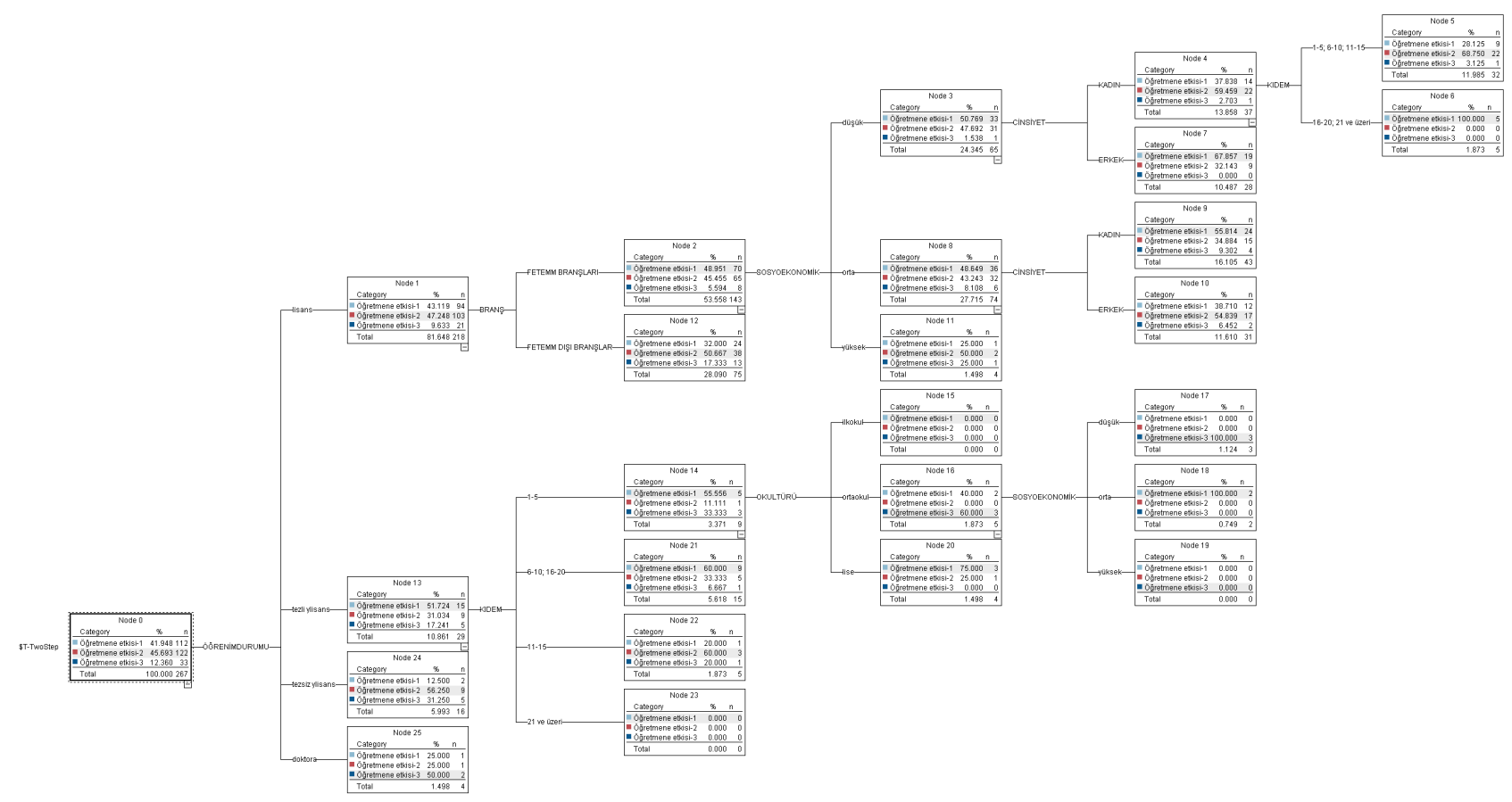

Şekil 6. FeTeMM Farkındalık Ölçeği'nin “Öğretmene Etkisi” Boyutuna ilişkin C5.0 Algoritması ile Elde Edilen Karar Ağacı

Şekil 6 incelendiğinde, FeTeMM Farkındalık Ölçeği' nin "öğretmene etkisi” boyutunu açıklayan 25 düğüm olduğu görülmektedir. Bu boyutu en iyi açıklayan değişken "öğrenim durumu"dur. Lisans mezunu öğretmenlerin \%47.25'i, tezsiz yüksek lisans mezunu öğretmenlerin \%56.25'i FeTeMM Farkındalık Ölçeği'nin "öğretmene etkisi" boyutuna ilişkin orta düzey, tezli yüksek lisans mezunu öğretmenlerin \%51.72'si düşük düzey, doktora mezunu öğretmenlerin $\% 50.00$ ' 1 yüksek düzey farkındalığa sahiptirler.

Lisans mezunu öğretmenlerin oluşturduğu kümeyi en iyi açılayan değişken "branş"tır. Buna göre, FeTeMM branşlarında lisans mezunu öğretmenlerin \%48.95'i FeTeMM Farkındalık Ölçeği'nin “öğretmene etkisi" boyutuna ilişkin düşük düzey, FeTeMM dışı branşlarda lisans mezunu öğretmenlerin \%50.67'si orta düzey farkındalığa sahiptirler.

FeTeMM branşlarında lisans mezunu öğretmenlerin oluşturduğu kümeyi en iyi açılayan değişken "okulların sosyoekonomik düzeyi"dir. Sosyoekonomik açıdan düşük düzey okullarda görev yaptıklarını belirten, FeTeMM branşlarında lisans mezunu öğretmenlerin \%50.77'si, sosyoekonomik açıdan orta düzey okullarda görev yaptıklarını belirten, FeTeMM branşlarında lisans mezunu öğretmenlerin \%48.65'i FeTeMM Farkındalık Ölçeği'nin "öğretmene etkisi" boyutuna ilişkin düşük düzey farkındalığa sahiptirler. Sosyoekonomik açıdan yüksek düzey okullarda görev yaptıklarını belirten, FeTeMM branşlarında lisans mezunu öğretmenlerin \%50'si orta düzey farkındalığa sahiptirler.

Sosyoekonomik açıdan düşük ve orta düzey okullarda görev yaptıklarını belirten, FeTeMM branşlarında lisans mezunu olan öğretmenlerin oluşturduğu kümeyi en iyi açıklayan değişken "cinsiyet"tir. Sosyoekonomik açıdan düşük düzey okullarda görev yaptıklarını belirten, FeTeMM branşlarında lisans mezunu olan kadın öğretmenlerin \%59.46'sı FeTeMM Farkındalık Ölçeği'nin “öğretmene etkisi” boyutuna ilişkin orta düzey, erkek öğretmenlerin \%67.86'sı düşük düzey farkındalığa sahiptirler. Sosyoekonomik açıdan orta düzey okullarda görev yaptıklarını belirten, FeTeMM branşlarında lisans mezunu olan kadın öğretmenlerin \%55.81'i FeTeMM Farkındalık Ölçeği'nin “öğretmene etkisi” boyutuna ilişkin düşük düzey, erkek öğretmenlerin $\% 54.84$ 'ü orta düzey farkındalığa sahiptirler.

Sosyoekonomik açıdan düşük düzey okullarda görev yaptıklarını belirten, FeTeMM branşlarında lisans mezunu olan kadın öğretmenlerin oluşturduğu kümeyi en iyi açıklayan değişken "kıdem" dir. Bu değişken bağımlı değişkeni iki gruba ayırmıştır. Buna göre sosyoekonomik açıdan düşük düzey okullarda görev 
yaptıklarını belirten, FeTeMM branşlarında lisans mezunu öğretmenlerden 1-15 yıl kıdeme sahip kadın öğretmenlerin \%68.75'i FeTeMM Farkındalık Ölçeği' nin “öğretmene etkisi” boyutuna ilişkin orta düzey, 16 yıl ve üzeri kıdeme sahip kadın öğretmenlerin \%100'ü düşük düzey farkındalığa sahiptirler.

Tezli yüksek lisans mezunu öğretmenlerin oluşturduğu kümeyi en iyi açıklayan değişken "kıdem"dir. Bu değişken bağımlı değişkeni dört gruba ayırmıştır. Tezli yüksek lisans mezunu 11-15 yıl kıdeme sahip öğretmenlerin \%60.00’ 1 FeTeMM Farkındalık Ölçeği'nin “öğretmene etkisi” boyutuna ilişkin orta düzey, 1-5 yıl kıdeme sahip öğretmenlerin \%55.56'sı, 6-10 ve 16-20 yıl kıdeme sahip öğretmenlerin \%60'ı düşük düzey farkındalığa sahiptirler.

Tezli yüksek lisans mezunu, 1-5 yıl kıdeme sahip öğretmenlerin oluşturduğu kümeyi en iyi açılayan değişken "okul türü" dür. Tezli yüksek lisans mezunu, 1-5 yıl kıdeme sahip ortaokullarda görev yapan öğretmenlerin \%60'ı FeTeMM Farkındalık Ölçeği'nin "öğretmene etkisi” boyutuna ilişkin yüksek düzey, lisede görev yapan öğretmenlerin \%75 gibi büyük çoğunluğu düşük düzey farkındalığa sahiptirler.

Tezli yüksek lisans mezunu, 1-5 yıl kıdeme sahip, ortaokullarda görev yapan öğretmenlerin oluşturduğu kümeyi en iyi açıklayan değişken "okulların sosyoekonomik düzeyi"dir. Tezli yüksek lisans mezunu, 1-5 yıl kıdeme sahip, sosyoekonomik açıdan düşük düzey ortaokullarda görev yaptıklarını belirten öğretmenlerin \%100'ü FeTeMM Farkındalık Ölçeği'nin “öğretmene etkisi” boyutuna ilişkin yüksek düzey, sosyoekonomik açıdan orta düzey ortaokullarda görev yaptıklarını belirten öğretmenlerin \%100'ü ise düşük düzey farkındalığa sahiptirler.

\section{Sonuç ve Tartışma}

$\mathrm{Bu}$ araştırma ile öğretmenlerin FeTeMM eğitimi farkındalıkları üzerinde anlamlı etkisi olan yordayıcı değişkenlerin belirlenmesi ve önem sırasının ortaya konulması amaçlanmıştır. Araştırmada FeTeMM Farkındalık Ölçeği'nin öğrenciye, derse ve öğretmene etkisi boyutlarına ilişkin öğretmenlerin çoğunun orta düzey farkındalığa sahip oldukları ortaya çıkmışır. Benzer şekilde Baran ve diğerleri (2018) yapmış oldukları araştırmada, fen alanları öğretmenlerinin FeTeMM farkındalıklarının orta düzeyde, Çevik ve diğerleri (2017) yapmış oldukları araştırmada ortaokullarda görev yapan fen, matematik ve bilişim teknolojileri öğretmenlerinin FeTeMM eğitimine ilişkin farkındalıklarının olumlu ve orta seviyede olduğunu belirtmişlerdir. Ciğerci'nin (2020) yapmış olduğu araştırmada, okul yöneticisi ve öğretmenlerin FeTeMM'e ilişkin farkındalıkları incelenmiş, okul yöneticisi ve öğretmenlerin farkındalıklarının yüksek düzeyde olduğu tespit edilmiştir. Özdemir ve Cappellaro (2020) tarafından yapılmış olan bir araştırmada da sınıf öğretmenlerinin farkındalıklarının yüksek düzeyde olduğu ortaya çıkmıştır. Bakırcı ve Kutlu'nun (2018) yapmış oldukları bir başka araştırmada, fen bilimleri öğretmenlerinin FeTeMM eğitimine ilişkin yeterli bilgiye sahip olmadıkları tespit edilmiştir. Çevik ve diğerleri (2017) ülkemizde gerçekleştirilen FeTeMM eğitimine yönelik çalışmaların başlangıç aşamasında olduğundan dolayı öğretmen adayları, öğretmenler, okul yöneticileri ve öğrencilerin FeTeMM farkındalıklarının yetersiz olabileceğini belirtmişlerdir. Görüldüğü üzere, araştırmalarda öğretmenlerin FeTeMM eğitimine yönelik farkındalık düzeylerinde farklı sonuçlara ulaşılmıştır. Bunun nedeni, FeTeMM eğitimine yönelik farkındalık ile ilgili araştırmaların farklı yıllarda, farklı branşlarda, farklı kademelerde (ilkokul, ortaokul, lise) görev yapan öğretmenler ile yapılmış olabileceğinden kaynaklanabilir.

Araştırmada, FeTeMM Farkındalık Ölçeği'nin öğrenciye etkisi boyutu üzerinde etki düzeyi en yüksek olan yordayıcı değişkenin, öğretmenlerin görev yaptıkları okulların sosyoekonomik düzeyleri olduğu ortaya çıkmıştır. Sosyoekonomik açıdan yüksek düzey okullarda görev yaptıklarını belirten öğretmenlerin büyük çoğunluğu FeTeMM Farkındalık Ölçeği'nin öğrenciye etkisi boyutuna ilişkin yüksek düzeyde farkındalığa sahiptirler. Sosyoekonomik açıdan düşük ve orta düzey okullarda görev yaptıklarını belirten öğretmenlerin çoğu ise orta düzey farkındalığa sahiptirler. Bunun nedeni sosyoekonomik açıdan yüksek düzey okulların fiziki olanaklarının (FeTeMM Laboratuvarı, FeTeMM araç-gereçleri) daha iyi olması, bu okullarda öğrenim gören öğrencilerin ve velilerinin FeTeMM eğitimine ilişkin daha bilinçli olmaları ve bu konuda öğretmenlerini yönlendirmeleri olabilir. Bununla birlikte sosyoekonomik açıdan düşük düzey okullarda görev yaptıklarını 
belirten, 6-10 yıl kıdeme sahip olan öğretmenlerin çoğunun yüksek düzey farkındalığa sahip olduğu ve 21 yıl ve üzeri kıdeme sahip öğretmenlerin çoğunun ise düşük düzey farkındalığa sahip olduğu tespit edilmiştir. Benzer şekilde Çevik ve diğerleri (2017) yapmış oldukları araştırmada, özellikle 6-10 yıllık tecrübeye sahip öğretmenlerin FeTeMM'e ilişkin farkındalıklarının olumlu olduğunu belirtmişlerdir. Karakaya ve diğerlerinin (2018) yapmış oldukları araştırmada 1-5 yıl mesleki deneyime sahip öğretmenlerin FeTeMM eğitimine ilişkin farkındalıklarının, 16-20 yıl kıdeme sahip olan öğretmenlere göre daha yüksek olduğu belirlenmiştir. Bu bulgunun nedeni, yakın zamanda mezun olan öğretmenlerin eğitim fakültelerinde aldıkları derslerde son yıllarda popüler bir yaklaşım olan FeTeMM eğitimine ilişkin bilgilendirilmeleri olabilir. Buna rağmen Ciğerci'nin (2020) yapmış olduğu araştırmada farklı sonuçlara ulaşılmıştır. Araştırmaya göre, 16 yıl ve üzeri kıdeme sahip olan öğretmenlerin diğer öğretmenlere göre FeTeMM eğitimine yönelik farkındalıklarının anlamlı düzeyde daha fazla olduğu sonucuna ulaşılmıştır. Dahası sosyoekonomik açıdan orta düzey olan ilk ve ortaokullarda görev yapan öğretmenlerin çoğu FeTeMM Farkındalık Ölçeği'nin öğrenciye etkisi boyutuna ilişkin orta düzey, liselerde görev yapan öğretmenlerin büyük çoğunluğu ise yüksek düzey farkındalığa sahiptirler. Buna rağmen Karakaya ve diğerlerinin (2018) yapmış oldukları araştırmada, fen bilimleri öğretmenlerinin FeTeMM eğitimine ilişkin farkındalıklarında görev yaptıkları okul türüne göre anlamlı farklılık görülmediği belirlenmiştir.

Araştırmada FeTeMM Farkındalık Ölçeği'nin derse etkisi boyutu üzerinde etki düzeyi en yüksek olan yordayıcı değişkenin ise öğretmenlerin öğrenim durumları olduğu ortaya çıkmıştır. Buna göre lisans ve tezli yüksek lisans mezunu olan öğretmenlerin çoğunun orta düzey, tezsiz yüksek lisans mezunu olan öğretmenlerin çoğunun ise düşük düzey farkındalığa sahip olduğu gözlenmiştir. Tezsiz yüksek lisans mezunu olan öğretmenlerin çoğunun, lisans ve tezli yüksek lisans mezunu olan öğretmenlerden düşük düzey farkındalığa sahip olmasının nedeni, tezsiz yüksek lisans mezunu öğretmenlerin eğitim fakültesi dışındaki bir fakülteden mezun oldukları için FeTeMM'e ilişkin daha az bilgilendirilmeleri olabilir. Çevik ve diğerleri (2017) yapmış oldukları araştırmada lisans ve lisansüstü mezunu öğretmenlerin FeTeMM'e bakış açılarının ön lisans mezunlarına göre daha olumlu olduğu çıkarımında bulunmuşlardır. Ayrıca araştırmada tezli yüksek lisans mezunu olup, ilkokulda görev yapan bir öğretmenin olduğu ve yüksek düzeyde farkındalığa sahip olduğu görülmüştür. Ayrıca tezli yüksek lisans mezunu olup, ortaokulda görev yapan öğretmenlerin büyük çoğunluğu FeTeMM Farkındalık Ölçeği'nin derse etkisi boyutuna ilişkin orta düzey, lisede görev yapan öğretmenlerin çoğu ise düşük düzey farkındalığa sahiptirler. İlk ve ortaokulda görev yapan öğretmenlerin lisede görev yapan öğretmenlere göre derse etkisi boyutuna ilişkin daha çok farkındalığa sahip olmalarının nedeni, Milli Eğitim Bakanlığı tarafından yayımlanan ve 2018 yılında uygulanmaya başlanan Fen Bilimleri Dersi Öğretim Programında (İlkokul ve Ortaokul 3., 4., 5., 6., 7. ve 8. sinıflar) doğrudan olmasa da dolaylı olarak mühendislik ve tasarım becerileri başlığı altında FeTeMM'e ilişkin kazanımlara yer verilmesinden kaynaklanabilir.

Araştırmada ortaya çıkan bir başka sonuç ise FeTeMM Farkındalık Ölçeği'nin öğretmene etkisi boyutu üzerinde etki düzeyi en yüksek olan yordayıcı değişkenin öğretmenlerin öğrenim durumları olduğudur. Lisans ve tezsiz yüksek lisans mezunu öğretmenlerin çoğu FeTeMM'e ilişkin orta düzey, tezli yüksek lisans mezunu öğretmenlerin çoğu düşük düzey, doktora mezunu öğretmenlerin çoğunluğu ise yüksek düzey farkındalığa sahiptirler. Bununla birlikte FeTeMM branşlarında lisans mezunu öğretmenlerin çoğu FeTeMM Farkındalık Ölçeği'nin öğretmene etkisi boyutuna ilişkin düşük düzey, FeTeMM dışı branşlarda lisans mezunu öğretmenlerin çoğu ise orta düzey farkındalığa sahiptirler. Dahası tezli yüksek lisans mezunu 11-15 yıl kıdeme sahip öğretmenlerin çoğu FeTeMM'e ilişkin orta düzey, 1-10 ve 16-20 yıl kıdeme sahip öğretmenlerin çoğu ise düşük düzey farkındalığa sahiptirler.

Sonuç olarak; araştırmada FeTeMM Farkındalık Ölçeği'nin her üç boyutuna ilişkin öğretmenlerin çoğunun orta düzey farkındalığa sahip oldukları ve "öğrenciye etkisi" boyutu üzerinde etki düzeyi en yüksek olan yordayıcı değişkenin öğretmenlerin görev yaptıkları okulların sosyoekonomik düzeyleri, "derse etkisi" ve "öğretmene etkisi" boyutları üzerinde etki düzeyi en yüksek olan yordayıcı değişkenin ise öğretmenlerin öğrenim durumları olduğu ortaya çıkmıştır.

FeTeMM eğitiminin geliştirilmesi ve iyileştirilmesi amacı ile Milli Eğitim Bakanlığı ve üniversitelerin 
işbirliği ile FeTeMM eğitimi konusunda uzman kişilerce, öğretmenlere yönelik hizmet içi kurslar, seminerler, çalıştaylar düzenlenerek, FeTeMM merkezleri kurularak öğretmenlerin farkındalıkları arttırılabilir. Geleceğin öğretmenlerini yetiştiren kurumlar olan eğitim fakültelerinde FeTeMM eğitimine yönelik ders içeriklerine yer verilebilir. Öğretmenlerin FeTeMM farkındalıklarının yeterli düzeyde olmamasının nedenleri bir başka araştırma ile ortaya konulabilir. Bu araştırma Diyarbakır İlinde görev yapan öğretmenler ile yürütülmüştür. Farklı illerde, farklı örneklem gruplarının da dâhil edildiği benzer araştırmalar yapılabilir.

Literatürde, C5.0 karar ağacı algoritması kategorik hedef (bağımlı) değişkenleri tahmin etmede yaygın bir şekilde kullanılmaktadır. C5.0 algoritması, diğer karar ağacı algoritmalarıyla karşılaştırıldığında daha hızlı çalışır ve daha doğru kurallar üretir. Daha az bellek kullanması ve basit bir ağaç yapısı oluşturmasından dolayı (Yu ve diğerleri, 2018) anlaşılması ve yorumlanması kolaydır (Pang ve Gong, 2009). Ayrıca, diğer bazı karar ağacı algoritmalarında, ayırma işlemi ikili bölme işlemi esasına göre yapılırken, C5.0 algoritmasında çoklu dalların oluşturulduğu maksimum bilgi kazancı kullanılır (Balamurugan ve Kannan, 2016). Yukarıda bahsedilen tüm bu avantajlarından dolayı, bu çalışmada hedef (bağımlı) değişken iki aşamalı kümeleme analizi ile kategorik hale getirilmiş ve C5.0 algoritması tercih edilmiştir. Gelecek çalışmalarda, sürekli hedef (bağımlı) değişkenler ile çalışabilen, karar ağaçlarını sadece ikili dallara ayırabilen farklı algoritmalar tercih edilebilir ve analiz sonuçları karşılaştırılabilir.

\section{Yazar(lar)ın Beyanı}

Araştırmacıların katkı oramı beyanı: Araştırmanın tüm aşamaları yazar tarafından yapılmışıı.

Etik Kurul Kararı: Dicle Üniversitesi Sosyal ve Beşeri Bilimler Etik Kurulu Başkanlığın'dan E-14679147-663.0513968 sayılı etik kurulu onayı alınmıştır.

Çatışma beyanı: Herhangi bir kişi, kurum ya da kuruluşla çıkar çatışması bulunmamaktadır.

Destek ve teşekkür: Araştırma için herhangi bir kurum ya da kuruluştan destek alınmamıştır.

\section{Kaynaklar}

Akgündüz, D. \& Akpınar, B. C. (2018). Okul öncesi eğitiminde fen eğitimi temelinde gerçekleştirilen STEM uygulamalarının öğrenci, öğretmen ve veli açısından değerlendirilmesi. Yaşadıkça Eğitim, 32(1), 1-26.

Aksu, G. \& Reyhanlıoğlu-Keçeoğlu, Ç. (2019). Comparison of results obtained from logistic regression, CHAID analysis and decision tree methods. Eurasian Journal of Educational Research, 19(84), 115-134.

Albayrak, A. S. \& Koltan-Yılmaz, Ş. (2009). Veri madenciliği: Karar ağacı algoritmaları ve İMKB verileri üzerine bir uygulama. Süleyman Demirel Üniversitesi İktisadi ve İdari Bilimler Fakültesi Dergisi, 14(1), 31-52.

Bahçe, M. (2019). İlkokul 4. sını öğrencilerinin FeTeMM etkinlik uygulamalarının değerlendirilmesi (Yayınlanmamış yüksek lisans tezi). Dumlupınar Üniversitesi, Kütahya.

Bakırcı, H. \& Kutlu, E. (2018). Fen bilimleri öğretmenlerinin FeTeMM yaklaşımı hakkındaki görüşlerinin belirlenmesi. Türk Bilgisayar ve Matematik Eğitimi Dergisi, 9(2), 367-389.

Balamurugan, M. \& Kannan, S. (2016, October). Performance analysis of CART and C5.0 using sampling techniques. IEEE International Conference on Advances in Computer Applications (ICACA) (pp. 72-75). IEEE. Erişim adresi: https://ieeexplore.ieee.org/stamp/stamp.jsp?arnumber=7887926

Balcı, F. (2020). FeTeMM (STEAM) temelli öğretim tekniklerinin ortaokul 7. sinı öğrencilerinin rasyonel sayılar konusunda kavramsal değiş̧imlerine ve başarılarına etkisi (Yayınlanmamış yüksek lisans tezi). Yüzüncü Yıl Üniversitesi, Van.

Baran, M., Baran-Türkan, M., Aslan-Efe, H. \& Maskan, A. (2018, Haziran). Fen alanları öğretmenlerinin fen, teknoloji, matematik ve mühendislik (FeTeMM) farkındalık düzeylerinin çeşitli değişkenlere göre incelenmesi. ICPESS (International Congress on Politic, Economic and Social Studies), Niğde.

Bybee, R. W. (2010) Advancing STEM education: A 2020 vision. Technology and Engineering Teacher, 70(1), 30- 
35.

Ceylan, Z., Gürsev, S. \& Bulkan, S. (2017). İki aşamalı kümeleme analizi ile bireysel emeklilik sektöründe müşteri profilinin değerlendirilmesi. Bilişim Teknolojileri Dergisi, 10(4), 475-485.

Ciğerci, D. (2020). Okul yöneticilerinin ve öğretmenlerin FeTeMM eğitimine yönelik farkındalıklarının incelenmesi (Yayınlanmamış yüksek lisans tezi). Maltepe Üniversitesi, İstanbul.

Çalış, A., Kayapınar, S. \& Çetinyokuş, T. (2014). Veri madenciliğinde karar ağacı algoritmaları ile bilgisayar ve internet güvenliği üzerine bir uygulama. Endüstri Mühendisliği Dergisi, 25(3-4), 2-19.

Çevik, M. (2017). Ortaöğretim öğretmenlerine yönelik FeTeMM farkındalık ölçeği (FFÖ) geliştirme çalışması. Journal of Human Sciences, 14(3), 2436-2452.

Çevik, M., Danıştay, A. \& Yağcı, A. (2017). Ortaokul öğretmenlerinin FeTeMM (fen-teknoloji-mühendislikmatematik) farkındalıklarının farklı değişkenlere göre değerlendirilmesi. Sakarya University Journal of Education, 7(3), 584-599.

Çolakoğlu, M. H. \& Günay-Gökben, A. (2017). Türkiye'de eğitim fakültelerinde FeTeMM (STEM) çalışmaları. İnformal Ortamlarda Araştırmalar Dergisi, 2(2), 46-69.

Daşdemir, İ., Cengiz, E. \& Aksoy, G. (2018). Türkiye'de FeTeMM (STEM) eğitimi eğilim araştırması. Yüzüncü Yıl Üniversitesi Ĕ̆itim Fakültesi Dergisi, 15(1), 1161-1183.

Desimone, L. M. (2009). Improving impact studies of teachers' development toward better conceptualizations and measures. Educational Researcher, 38(3), 181-199.

Duygu, E. (2018). Simülasyon tabanlı sorgulayıcı öğrenme ortamında FeTeMM eğitiminin bilimsel süreç becerileri ve FeTeMM farkındalıklarına etkisi (Yayınlanmamış yüksek lisans tezi). Kırıkkale Üniversitesi, Kırıkkale.

Ergün, A. \& Balçın, M. D. (2019). Probleme dayalı FeTeMM uygulamalarının akademik başarıya etkisi. Sınırsız Eğitim ve Araştırma Dergisi, 4(1), 40-63.

Fore, G. A., Feldhaus, C. R., Sorge, B. H., Agarwal, M. \& Varahramyan, K. (2015). Learning at the nano-level: Accounting for complexity in the internalization of secondary STEM teacher professional development. Teaching and Teacher Education, 51, 101-112.

Fraenkel, J. R., Wallen, N. E. \& Hyun, H. H. (2012). How to design and evaluate research in education (8. Bask1). McGraw-Hill.

Gonzalez, H. B. \& Kuenzi, J. J. (2012, August). Science, technology, engineering, and mathematics (STEM) education: A primer. Washington, DC: Congressional Research Service, Library of Congress. Erişim adresi: https://fas.org/sgp/crs/misc/R42642.pdf

Guskey, T. R. (2002). Professional development and teacher change. Teachers and Teaching: Theory and Practice, $8(3), 381-391$.

Güleryüz, H., Dilber, R. \& Erdoğan, İ. (2019). STEM uygulamalarında öğretmen adaylarının 3D yazıcı kullanımı hakkındaki görüşleri. A ̆ğı İbrahim Çeçen Üniversitesi Sosyal Bilimler Enstitüsü Dergisi, 5(2), 1-8.

Gülseven, E. (2020). Argümantasyon temelli FeTeMM eğitiminin 7. sinı öğrencilerinin kuvvet ve enerji ünitesine yönelik akademik başarıların, tutumlarına ve argümantasyon seviyelerine etkisi (Yayınlanmamış yüksek lisans tezi). Yüzüncü Yıl Üniversitesi, Van.

Karakaya, F., Ünal, A., Çimen, O. \& Yılmaz, M. (2018). Fen bilimleri öğretmenlerinin STEM yaklaşımına yönelik farkındalıkları. Ĕ̆itim ve Toplum Araştırmaları Dergisi, 5(1), 124-138.

Kayri M. (2007), Araştırmalarda iki aşamalı kümeleme analizi ve bir uygulaması. Eurasian Journal of Educational Research, 28, 89-99.

Kayri, M., Elkonca, F., Şevgin, H. \& Ceyhan, G. (2014). Ortaokul öğrencilerinin fen ve teknoloji dersine yönelik 
tutumlarının CHAID analizi ile incelenmesi. Eğitim Bilimleri Araştırmaları Dergisi, 4(1), 301-316.

Korkut-Owen, F. \& Eraslan-Çapan, B. (2017). Ortaöğretim öğrencilerinin fen teknoloji matematik ve mühendislik alanlarını seçmeyi düşünme nedenleri. Yaşadıkça Ĕ̆itim, 31(2), 23-40.

Korkut-Owen, F. \& Mutlu, T. (2016). Türkiye'de fen bilimleri, teknoloji, mühendislik ve matematik alanlarının seçiminde cinsiyetler arası farklılıklar. Yaşadıkça Ĕ̆itim, 30(2), 53-72.

Koyunlu-Ünlü, Z. \& Dere, Z. (2019). Okul öncesi öğretmen adaylarının FeTeMM farkındalıklarının değerlendirilmesi. Erzincan Üniversitesi Eğitim Fakültesi Dergisi, 21(1), 44-55.

Köse, N. \& Ersöz, F. (2020). Veri madenciliğinde karar ağacı algoritmaları ile demir çelik endüstrisinde iş kazaları üzerine bir uygulama. Avrupa Bilim ve Teknoloji Dergisi, Özel Sayı, 397-407.

Milaturrahmah, N., Mardiyana, M. \& Pramudya, I. (2017, September). Mathematics learning process with science, technology, engineering, mathematics (STEM) approach in Indonesia. Journal of Physics: Conference Series. IOP Publishing. Erişim adresi: https://iopscience.iop.org/article/10.1088/1742-6596/895/1/012030/pdf

Milli Eğitim Bakanlığı (2016). STEM eğitimi raporu. Ankara.

Milli Eğitim Bakanlığı (2018). Fen bilimleri dersi öğretim programı. Ankara: Devlet Kitapları Müdürlüğü Basım Evi.

Özdemir, A. U. \& Cappellaro, E. (2020). Sınıf öğretmenlerinin FeTeMM farkındalıkları ve FeTeMM eğitimi uygulamalarına yönelik görüşleri. Fen Bilimleri Öğretimi Dergisi, 8(1), 46-75.

Pandya, R. \& Pandya, J. (2015). C5.0 algorithm to improved decision tree with feature selection and reduced error pruning. International Journal of Computer Applications, 117(16), 18-21.

Pang, S. L. \& Gong, J. Z. (2009). C5.0 classification algorithm and application on individual credit evaluation of banks. Systems Engineering-Theory and Practice, 29(12), 94-104.

Pehlivan, K. \& Uluyol, Ç. (2019). STEM ve eğitimde uygulama örneklerinin incelenmesi. Türkiye Sosyal Araştırmalar Dergisi, 23(3), 848-861.

Püsküllü, D. (2019). Ortaokul fen bilimleri öğretiminde STEM (FeTeMM) üzerine yapılmış lisansüstü tezlerin değerlendirilmesi (Yayınlanmamış yüksek lisans tezi). Mustafa Kemal Üniversitesi, Hatay.

Scientix Projesi (2020). Scientix Projesi. 9 Nisan 2020 tarihinde https://scientix.eba.gov.tr/ adresinden erişildi.

Thomasian, J. (2011). Building a science, technology, engineering, and math education agenda: An update of state actions. NGA Center for Best Practices.

Yıldırım, B. (2016). An analyses and meta-synthesis of research on STEM education. Journal of Education and Practice, 7(34), 23-33.

Yıldırım, B. \& Altun, Y. (2015). STEM eğitim ve mühendislik uygulamalarının fen bilgisi laboratuvar dersindeki etkilerinin incelenmesi. El-Cezeri Journal of Science and Engineering, 2(2), 28-40.

Yu, F., Li, G., Chen, H., Guo, Y., Yuan, Y. \& Coulton, B. (2018). A VRF charge fault diagnosis method based on expert modification C5. 0 decision tree. International Journal of Refrigeration, 92, 106-112. 


\section{EXTENDED ABSTRACT}

\section{Introduction}

Today, the need for individuals who are thinking, producing, questioning and creative is increasing in science, technology, engineering and mathematics. Accordingly, it is essential to implement new and different programs for learning-teaching processes in these fields. The newest of these practices is STEM education and applications (Ylldırım and Altun, 2015). Providing STEM education in accordance with its purpose is directly associated with teachers' awareness, professional knowledge, experience and skills on this subject. As STEM education awareness refers to being conscious and sensitive about STEM education (Koyunlu-Ünlü and Dere, 2019), it is of importance to determine the awareness of teachers regarding STEM education. However, in the literature search carried out, no study has been found in which variables that predict teachers' STEM awareness were analyzed using the C5.0 algorithm, which is one of the decision tree methods. As determining independent variables, which are effective on dependent variable, is one of the basic purposes of scientific research (Aksu and Reyhanlığlu-Keçeoğlu, 2019), this study aims to identify the independent variables, which are effective on teachers' awareness of STEM education and to rank them according to an order of importance.

\section{Method}

In the research, correlational survey model was used. The participants of the study consisted of 267 teachers. "Personal Information Form" and "STEM Awareness Scale (SAS)" were administered to the teachers who participated in the study. The scale was developed by Çevik (2017). The scale was designed in 5-Likert type, consisted of fifteen items and had three factors. The dimensions of the scale are "Effect on Students", "Effect on Lessons", "Effect on Teachers". Based on the data obtained, Two-Stage Clustering Analysis and C5.0 Decision Tree Algorithm were administered using the "SPSS Clementine 12.0" program.

\section{Results}

In the research, it was found out that $47.19 \%$ of the teachers had moderate level awareness regarding the dimension of "effect on student" dimension of STEM awareness scale. In addition, it was seen that there were 13 nodes explaining this dimension. The variable explaining this dimension most was "socioeconomic levels of schools". $75 \%$ of teachers, who stated that they worked in high-level schools in socioeconomic terms, had a high level of awareness about STEM. On the other hand, $49.58 \%$ of teachers, who expressed that they worked in low-level schools in socioeconomic terms, and $49.24 \%$ of teachers, indicating that they worked in moderatelevel schools in socioeconomic terms had a moderate level of awareness about STEM.

In the investigation, it was identified that $53.93 \%$ of the teachers had moderate level awareness regarding the dimension of "effect on lesson" dimension of STEM awareness scale. Moreover, it was observed that there were 6 nodes explaining this dimension. The variable explaining this dimension most was "educational background". While $55.96 \%$ of the teachers with a bachelor's degree and $51.72 \%$ of the teachers with a master degree with thesis had moderate level awareness, $45 \%$ of the teachers with a master degree without thesis and PhD degree had low level awareness.

In the study, it was concluded that $45.69 \%$ of the teachers had moderate level awareness regarding the dimension of "effect on teacher" dimension of STEM awareness scale. Moreover, it was observed that there were 25 nodes explaining this dimension. The variable explaining this dimension most was "educational background". $47.25 \%$ of the teachers with a bachelor's degree and $56.25 \%$ of the teachers with a master degree with thesis had moderate level awareness, whereas $51.72 \%$ of the teachers with a master degree without thesis and $50.00 \%$ of the teachers with a PhD degree had high-level awareness.

\section{Conclusion}

It has been concluded in the study that the teachers generally have moderate level awareness regarding the dimensions of "Effect on Students", "Effect on Lessons", "Effect on Teachers" of the STEM awareness scale. In a similar vein, Çevik etc. (2017) indicated that teachers' awareness of STEM is positive and in moderate 
level. It has been achieved in the study that the predictor variable with the highest level of effect on the "effect on student" dimension of STEM awareness scale is the socioeconomic level of the schools where teachers worked. Most of the teachers, who stated that they worked in high-level schools in socioeconomic terms, have high level awareness of STEM. On the other hand, most of the teachers, who expressed that they worked in moderate and low-level schools in socioeconomic terms, have moderate level awareness of STEM. This may be caused by the fact that the schools with high socioeconomic conditions have better physical opportunities (STEM Laboratory, STEM tools and equipment), the students enrolled in these schools and their parents are more conscious about STEM, and they urge the teachers in this respect. In the research, it has been identified that the predictor variable with the highest level of effect on the "effect of lesson" dimension of STEM awareness scale is the educational background of the teachers. Accordingly, it has been observed that while most of the teachers with a bachelor's degree and a master degree have moderate level awareness regarding STEM, most of the teachers with a master degree without thesis and a PhD degree have low-level awareness. Another conclusion achieved is that the predictor variable with the highest level of effect on the "effect on teacher" dimension of STEM awareness scale is the educational background of teachers. Most of the teachers with a bachelor's degree and a master degree without thesis have moderate level awareness on STEM, whereas most of the teachers a master degree with thesis have low level, and most of the teachers with a PhD degree have high-level awareness about STEM.

Suggestions are made in accordance with the conclusions obtained. In order to develop and improve STEM education, the awareness of teachers on STEM education may be raised by organizing in-service courses, seminars, workshops by the individuals specialized in STEM education through the Ministry of National Education and universities. 